\title{
Addendum: Miniaturized Technologies for Enhancement of Motor Plasticity
}

\section{Samira Moorjani*}

Department of Physiology and Biophysics, and the Washington National Primate Research Center, University of Washington, Seattle, WA, USA

\section{OPEN ACCESS}

Edited and Reviewed by: Silke Krol,

Fondazione IRCCS Istituto Neurologico "Carlo Besta", Italy

${ }^{*}$ Correspondence: Samira Moorjani moorjani@u.washington.edu

Specialty section: This article was submitted to Nanobiotechnology,

a section of the journal Frontiers in Bioengineering and Biotechnology

Received: 19 May 2016 Accepted: 01 June 2016 Published: 13 June 2016

Citation: Moorjani S (2016) Addendum: Miniaturized Technologies for Enhancement of Motor Plasticity. Front. Bioeng. Biotechnol. 4:51. doi: 10.3389/fbioe.2016.00051

Keywords: motor plasticity, motor repair, brain-computer interfaces, neuromodulator delivery, optical neural interfaces, hybrid neuroprostheses, miniaturization

\section{An Addendum on}

Miniaturized Technologies for Enhancement of Motor Plasticity

by Moorjani, S. (2016). Front. Bioeng. Biotechnol. 4:30. doi: 10.3389/fbioe.2016.00030

\section{Reason for Addendum:}

In the original article, I neglected to thank a couple of sponsors, which are now included below (with the original Acknowledgments).

\section{ACKNOWLEDGMENTS}

I am very grateful to Eberhard E. Fetz for reviewing this article and providing critical feedback. I would also like to acknowledge financial support from the Center for Sensorimotor Neural Engineering, a National Science Foundation Engineering Research Center (EEC-1028725). Additional funding for this work was provided by the National Institutes of Health (RO1-NS-12542 and P51-RR-0016).

Copyright (C) 2016 Moorjani. This is an open-access article distributed under the terms of the Creative Commons Attribution License (CC BY). The use, distribution or reproduction in other forums is permitted, provided the original author(s) or licensor are credited and that the original publication in this journal is cited, in accordance with accepted academic practice. No use, distribution or reproduction is permitted which does not comply with these terms. 